\title{
Michel Zumkir, Nicole Malinconi, l'écriture au risque de la perte
}

\section{Chiara Rolla}

\section{Q OpenEdition}

1 Journals

\section{Edizione digitale}

URL: http://journals.openedition.org/studifrancesi/30837

DOI: 10.4000/studifrancesi.30837

ISSN: 2421-5856

\section{Editore}

Rosenberg \& Sellier

\section{Edizione cartacea}

Data di pubblicazione: 1 avril 2006

Paginazione: 195

ISSN: 0039-2944

\section{Notizia bibliografica digitale}

Chiara Rolla, «Michel Zumkir, Nicole Malinconi, l'écriture au risque de la perte», Studi Francesi [Online], 148 (XLX | I) | 2006, online dal 30 novembre 2015, consultato il 22 avril 2021. URL: http://

journals.openedition.org/studifrancesi/30837 ; DOI: https://doi.org/10.4000/studifrancesi.30837

Questo documento è stato generato automaticamente il 22 avril 2021.

\section{(c) (i) $\odot$}

Studi Francesi è distribuita con Licenza Creative Commons Attribuzione - Non commerciale - Non opere derivate 4.0 Internazionale. 


\title{
Michel Zumkir, Nicole Malinconi, l'écriture au risque de la perte
}

\author{
Chiara Rolla
}

\section{NOTIZIA}

MICHEL zUMKIR, Nicole Malinconi, l'écriture au risque de la perte, Avin, éd. Luce Wilquin, 2004, pp. 188.

1 Dal 1984, anno della sua nascita alla scrittura, Nicole Malinconi continua ad interrogare il mondo nei suoi aspetti più quotidiani attraverso romanzi di ispirazione autobiografica, novelle o testi brevi. Come sottolinea ZUMKIR, scrivere è per lei un atto di resistenza all'oblio, ma è anche un esporsi al rischio della perdita dell'essere: «Ecrire sur rien. Ecrire rien. Non. Même pas rien. Juste : écrire. Ecrire intransitivement» (pp. 63).

2 Il volume è composto di tre parti. Dopo aver ripercorso la biografia dell'autrice, ricostruendone i legami famigliari, la vita lavorativa, l'incontro con Minuit che pubblica Hôpital silence (Première partie), l'A. tenta di stendere un inventario di alcune delle caratteristiche dell'opera della Malinconi, soffermandosi in particolare su alcuni romanzi (Hôpital silence, L'attente, Nous deux, Da solo, A l'étranger) (Deuxième partie). La terza ed ultima parte è costituita da un'antologia che annovera anche due testi inediti dell'autrice. 